\title{
Towards Expanding Quinoa Cultivation in Egypt: The Effect of Compost and Vermicompost on Quinoa Pests, Natural Enemies and Yield under Field Conditions
}

\author{
Hala Adel \\ Central Laboratory for Organic Agriculture, Agricultural Research Center, Cairo, Egypt \\ Email: halaade13528@gmail.com
}

How to cite this paper: Adel, H. (2020) Towards Expanding Quinoa Cultivation in Egypt: The Effect of Compost and Vermicompost on Quinoa Pests, Natural Enemies and Yield under Field Conditions. Agricultural Sciences, 11, 191-209.

https://doi.org/10.4236/as.2020.112012

Received: January 31, 2020

Accepted: February 21, 2020

Published: February 24, 2020

Copyright $\odot 2020$ by author(s) and Scientific Research Publishing Inc. This work is licensed under the Creative Commons Attribution International License (CC BY 4.0).

http://creativecommons.org/licenses/by/4.0/

\begin{abstract}
Increasing production and reducing pests' population while preserving the environment is an essential goal nowadays. New strategies are needed to achieve this goal, to bridge food gap and achieve food security. Quinoa is a promising crop and could partially substitute wheat in baked products and assist in overcoming wheat gap in Egypt. This study aimed to identify pests and their natural enemies in quinoa plantation, the population dynamics of both and the effect of compost and vermicompost fertilization on pests' population and quinoa yield under field conditions. The study was carried out in El Giza Research Station of the Agricultural Research Centre-Egypt, from November till March, in two successive seasons, 2016/2017 and 2017/2018. The experiment was set up in a complete randomized block design. Variety Masr 1 was tested and yellow sticky traps were used to monitor insects' numbers. Three main pests were detected: Aphis craccivora, Empoasca. decipiens and Bemisia tabaci. The most common pest was aphids followed by potato leafhoppers. Compost fertilized quinoa attracted fewer pests and resulted in less yield compared to vermicompost. Parasitoids appeared earlier than predators and their numbers were the highest throughout the two seasons. Pests' and natural enemies' peaks were determined to facilitate IPM interventions. It is recommended to use vermicompost in quinoa production rather than compost, as it increased yield, provided that an IPM strategy is implemented in which natural enemies are the main players. Further investigations are needed to understand the interaction between predators and parasitoids in quinoa field in order to maximize the benefit of their existence in IPM programs.
\end{abstract}

\section{Keywords}

Quinoa, Organic Fertilization, Pests, Parasitoids, Predators, Population Dynamics 


\section{Introduction}

Quinoa (Chenopodium quinoa Wilid.) is one of the goosefoot family members (Chenopodiaceae) [1]. It was selected by FAO as one of the crops destined to offer food security in the next century [2]. Quinoa is a grain that has exceptional characteristics, i.e. it is gluten-free, has high nutritional value properties with an average of $14.8 \%$ protein and an extraordinary balance between starch, oil and protein [3]. Its high protein contents strengthen the immune system and assist in fighting various diseases including cancer [4]. Quinoa is also high in lysine value, in addition to manganese, magnesium, iron and vitamin B2 that are essential for growth, metabolism, and enzymes functions in the body [5] [6] [7].

Egypt has an area of about 1 million $\mathrm{km}^{2}$, most of which is under arid and hyper-arid climatic conditions; only $3 \%$ is used in agricultural production [8]. According to Jacobsen et al. [9], no crop other than quinoa can resist the combination of adverse factors, and therefore, a national campaign to expand the cultivation of quinoa has been launched by the Egyptian Ministry of Agriculture [10] due to its adaptability to adverse climate and soil conditions [11], in addition to its tolerant to drought and salinity [12] and its low production cost attributed to the low inputs and labor needed. Quinoa, therefore, can play a key role in food production in Egyptian reclaimed desert lands [13]. It is hoped also that this initiative will reduce the country's dependence on wheat imports. Historically, quinoa was first introduced in Egypt in 2005, being first cultivated in South Sinai. The cultivated area of quinoa has reached more than 80 feddans $(1$ feddan $=$ 0.42 hectare) in the period since 2010 [10].

Despite all these advantages, quinoa is attacked by a wide variety of insect pests that can cause damage during its different life stages and even in storage as stated by Oelke et al. [14]. Reports from Northern and Southern Europe identified Aphis fabae L. (Homoptera Aphididae) and leafhoppers (Homoptera Cicadellidae) as pests causing injury in quinoa [15] [16]. Furthermore, Tawfik et al. [17] identified aphids, Tuta absoluta and cotton leaf worm as pests attacking quinoa plants in different places in Egypt and caused considerable yield damage.

Organic crops proved to be more tolerant/resistant to insect infestation [18]. The same conclusion was mentioned by Altieri et al. [19] who stated that organic farming practices offer balanced nutrition to crops and thus they become less susceptible to insect pests and diseases. Not only insect's pests are affected by the type of fertilization but also the natural enemies of those pests [20]. Vermicompost has been advocated as good organic manure for use in integrated management practices in field crops. Vermicompost not only increases organic carbon status of the soils but also increases soil water holding capacity, flocculation of soil and availability of nutrients and thus improves soil and crop production sustainability [21] In addition, fertilization with compost showed higher values in most quality traits of biomass in quinoa crop other than synthetic fertilizers [22]. In comparing the effect of compost and vermicompost on Amaranthus viridis production; Islam et al. [23] found that vermicompost application gave higher 
result for growth, yield indices and nutrient content than the conventional aerobic compost. In the present investigation, the two organic fertilizers were chosen as they provide all nutrients in readily available forms and also enhance uptake of nutrients by plants and play a major role in improving growth and yield of different field crops [24]. Consequently, this study aimed to identify pests attacking quinoa crop under Egyptian conditions, the population dynamics of these pests together with their natural enemies in relation to the fertilization with compost and vermicompost. In addition, the effect of these two organic fertilizers on quinoa production yield was also investigated.

\section{Materials and Methods}

\subsection{Experiment Location}

The present study was carried out in El Giza Research Station affiliated to the Agricultural Research Centre (ARC) - Egypt. El Giza Governorate is located on the west bank of the Nile, $4.9 \mathrm{~km}$ southwest of central Cairo on $30.01^{\circ} \mathrm{N}$ latitudes and $31.21^{\circ} \mathrm{E}$ longitude. A soil analysis test was carried out in the Soil, Water and Environment Research Institute, ARC, to identify the soil properties in the experimental area. The analysis showed that the soil is clay with $36.3 \%$ clay, $37.6 \%$ silt and $26.1 \%$ sand. Percentages of organic matter, nitrogen, phosphorus and potassium were $1,0.003,0.001$ and 0.03 , respectively. Soil $\mathrm{pH}$ was 7.73 whereas EC, wilting point and field capacity recorded $0.5 \mathrm{ds} / \mathrm{m}, 20.2 \%$ and $43.8 \%$, respectively.

\subsection{Experiment Date and Weather Conditions}

The study extended from November till March, in two successive seasons, $2016 / 2017$ and 2017/2018. Quinoa was sown on $20^{\text {th }}$ of November of each season. Weather conditions including average temperature, average relative humidity, precipitation and average wind speed were daily recorded with the assistance of colleagues in the Central Laboratory for Agricultural Climate, ARC (Table 1). The climate is arid, characterized by no precipitation during the experiment period, relative humidity was moderate most of the time and wind speed was light as it did not exceed $0.8 \mathrm{~m} / \mathrm{sec}$.

\subsection{Organic Fertilizers}

Two types of fertilizers were used, i.e. compost and vermicompost made up of plant wastes and cattle manure (in case of vermicompost the earth worm Eisenia foetida was used). Both fertilizers were provided by the Central Laboratory of Organic Agriculture (CLOA), ARC. Compost and vermicompost were incorporated in the soil before sowing quinoa at rates of 5 and $4 \mathrm{~m}^{3} / \mathrm{feddan}$, respectively ( 1 feddan $=0.42$ hectare). Table 2 and Table 3 present the compost and vermicompost analyses that were carried out in CLOA.

\subsection{Design and Cultivation}

Treatments were arranged in a complete randomized block design. There were 
Table 1. Weather conditions during the experimental period (November-March) in the two seasons 2016-17 and 2017-18.

\begin{tabular}{ccccc}
\hline \multicolumn{5}{c}{ Season 2016/2017 } \\
\hline Months & $\begin{array}{c}\text { Aver. wind } \\
\text { speed [m/sec] }\end{array}$ & $\begin{array}{c}\text { Aver. } \\
\text { temperature }\left({ }^{\circ} \mathrm{C}\right)\end{array}$ & $\begin{array}{c}\text { Aver. relative } \\
\text { humidity [\%] }\end{array}$ & $\begin{array}{c}\text { Precipitation } \\
\text { sum [mm] }\end{array}$ \\
\hline November & 0.6 & 20.3 & 59.4 & 0.0 \\
December & 0.5 & 14.7 & 61.4 & 0.0 \\
January & 0.6 & 14.0 & 59.2 & 0.0 \\
February & 0.8 & 16.1 & 57.6 & 0.0 \\
March & 0.8 & 19.1 & 53.1 & 0.0 \\
\hline & & Season $2017 / 2018$ & & 0.0 \\
\hline November & 0.7 & 20.4 & 57.6 & 0.0 \\
December & 0.6 & 18.1 & 62.6 & 0.0 \\
January & 0.7 & 16.2 & 57.1 & 0.2 \\
February & 0.4 & 17.5 & 59.3 & 0.0 \\
March & 0.6 & 21.2 & 48.0 & \\
\hline
\end{tabular}

Table 2. Results of compost analysis.

\begin{tabular}{cccccccccccccc}
\hline \multicolumn{10}{c}{ Parameters and Minerals } \\
\hline $\mathrm{pH}$ & $\mathrm{Fe}(1: 10) \mathrm{ds} / \mathrm{m}$ & $\mathrm{OC} \%$ & $\mathrm{~N} \%$ & $\mathrm{P} \%$ & $\mathrm{~K} \%$ & $\mathrm{Ca} \%$ & $\mathrm{Mg} \%$ & Moist \% & Org. $\mathrm{m} . \%$ & $\mathrm{C}: \mathrm{N}$ & $\mathrm{H}_{2} \mathrm{~S}$ & $\mathrm{Ws}$ & $\mathrm{Nem}$. \\
\hline 7.53 & 2.67 & 27.1 & 1.2 & 0.9 & 0.8 & 0.4 & 0.7 & 28 & 30 & $20: 1$ & - & - & -
\end{tabular}

Ws $=$ Weed seeds, Nem. Nematodes.

Table 3. Results of vermicompost analysis.

\begin{tabular}{cccccccccccccc}
\hline \multicolumn{10}{c}{ Parameters and Minerals } \\
\hline $\mathrm{pH}$ & $\mathrm{EC} \mathrm{(1:10)} \mathrm{ds} / \mathrm{m}$ & OC $\%$ & $\mathrm{~N} \%$ & $\mathrm{P} \%$ & $\mathrm{~K} \%$ & $\mathrm{Ca} \%$ & $\mathrm{Mg} \%$ & Moist \% & Org. $\mathrm{m}$. & $\mathrm{C}: \mathrm{N}$ & $\mathrm{H}_{2} \mathrm{~S}$ & Ws & Nem. \\
\hline 7.7 & 1.3 & 40.2 & 2.4 & 1.7 & 1.1 & 0.8 & 0.6 & 30 & 68.4 & $17: 1$ & - & - & - \\
\hline
\end{tabular}

Ws $=$ Weed seeds, Nem. Nematodes.

three replicates for each treatment, i.e. compost, vermicompost, and untreated control. Each plot had an area of $21 \mathrm{~m}^{2}$ and consisted of 10 rows, every row measured $6 \mathrm{~m}$ long and $3.5 \mathrm{~m}$ width. Space between rows was adjusted to $60 \mathrm{~cm}$; whereas, within-row spacing between plants was $20 \mathrm{~cm}$. Quinoa grains, variety Masr 1, were provided by the Department of Maize and Sugar Crops, Plant Pathology Research Institute, ARC. After one month of cultivation quinoa plants were thinned to 2 plants per hill. All agronomic practices were maintained constantly when required. Manual weed control was carried out when necessary and quinoa was irrigated monthly during the whole season (4 irrigations). No fungicide or pesticide treatments were applied.

\subsection{Data Collection}

\section{1) Pests, parasitoids and predators incidence}

Yellow sticky traps measuring $45 \times 25 \mathrm{~cm}$ were used to detect insects' num- 
bers attracted to quinoa crop under field conditions. Using sticky traps was encouraged by the low wind speed recorded during the experimental period as mention in Table 1. Four traps were used in each plot including the control plot. Three weeks post cultivation traps were hanged with the help of wooden stakes $30 \mathrm{~cm}$ above the top of the plants reversing wind direction. Traps were adjusted vertically whenever the crop attained additional growth and they were inspected every two weeks on a regular basis. Upon the collection of the sticky traps, they were wrapped with clear plastic cling film for protection, transferred to the laboratory for sorting, identifying and counting. The identification and counting of insects on the traps was carried out in the Plant Protection Research Institute, ARC. Meanwhile traps were replaced with new ones after each inspection date.

\section{2) Grain yield measurements}

Quinoa grains were harvested when about $95 \%$ of the plants reached maturation phase. Ten plants were randomly chosen from each plot, bulked and weighted. Grain yield/plot was measured and converted to $\mathrm{Kg} / \mathrm{ha}$. In addition, a sample of 1000 seeds from the bulked seeds of each plot was weighed.

\subsection{Statistical Analysis}

Data were subjected to one way Analysis of Variance (ANOVA) and the treatment means were statistically differentiated by performing Least Square Means test (LSD) at $\mathrm{p}<0.05$ level using SPSS software.

\section{Results}

\subsection{Identification of Insects in Quinoa Field}

Upon the collection of the sticky traps, they were transferred to the laboratory for identification. Table 4 presents the insects pests, parasitoids and predators found on the sticky traps.

Table 4. Scientific classification of the insects on the yellow traps in quinoa field.

\begin{tabular}{ccccc}
\hline Type & Common name & Scientific name & Order & Family \\
\hline Pests & Black legume aphid & Aphis craccivora & Hemiptera & Aphididae \\
& Potato leafhoppers & Empoasca decipiens & & Cicadellidae \\
& Silver leaf whitefly & Bemisia tabaci & & Aleyrodidae \\
Predators & Green lacewing & Chrysoperla carnea & Neuroptera & Chrysopidae \\
& Lady bug & Coccinella vicina & Coleoptera & Coccinellidae \\
& Coccinella septempunctata & & \\
Parasitoids & Green bug aphids & Lysiphebus fabarum & Hymenoptera & Braconidae \\
& parasitoids & Lysiphebus testacoipes & & \\
& Aphids parasitoids & Bracon sp. & & \\
& Aphids parasitoids & Trioxys sp. & & \\
\hline
\end{tabular}




\subsection{Pests in Quinoa Field}

\section{1) Aphis craccivora}

The black legume aphid was one of the pests found in large numbers on the yellow sticky traps in quinoa field. Aphids' numbers fluctuated from December to March during the two seasons of the experiment in all the treatments, as illustrated in Figure 1. Aphids had two peaks (on January $23^{\text {rd }}$ and March $7^{\text {th }}$ ). Mean number of aphids' population \pm SD in compost, vermicompost and control treatments during the month of December were $29.7 \pm 4,57.7 \pm 4.1$ and 68.3 \pm 4.2 , respectively. One-Way ANOVA showed that there was a high significant difference between aphids mean numbers in the three treatments $(p=0.002)$. During the month of January aphids' population mean numbers in all treatments decreased and then increased again. In compost treatment, $9^{\text {th }}$ of January, it reached $14.3 \pm 3$, whereas, vermicompost and control treatments recorded $22.3 \pm 2.5$ and $37.3 \pm 3$, respectively. Results proved that there was a high significant difference between all the treatments, where $\mathrm{p}<0.001$. Two weeks later, on the $23^{\text {rd }}$ of the same month, mean numbers increased to reach $165 \pm 65,296 \pm 55$ and $232.3 \pm 3$ in the three treatments, respectively, with a significant difference between treatments $(\mathrm{p}=0.047)$.

February population, on the other hand, showed a slightly different trend in pest mean numbers where they decreased during the two periods of data collection. In compost treatments during the $7^{\text {th }}$ and $21^{\text {st }}$ of February, mean numbers of aphids recorded $149.7 \pm 8.9$ and $78 \pm 3$. Vermicompost recorded $177 \pm 9$ and $92 \pm 3.2$, whereas, aphids in control plots reached $182 \pm 9.1$ and $107.3 \pm 3$ in the two periods, respectively. Moreover, mean numbers continued to fluctuate again during the month of March where pest population increased on the $7^{\text {th }}$ of March, then decreased on the $21^{\text {st }}$ of March, as illustrated in Figure 1.

\section{2) Empoasca decipiens}

The potato leafhopper, Empoasca decipiens, did not appear in quinoa field till the last week of January, where its mean number in compost plot recorded $5.3 \pm$ 1.8 and increased in vermicompost and control treatments to reach $20 \pm 2$ and $25 \pm 1$, respectively. ANOVA test showed that there was a high significant

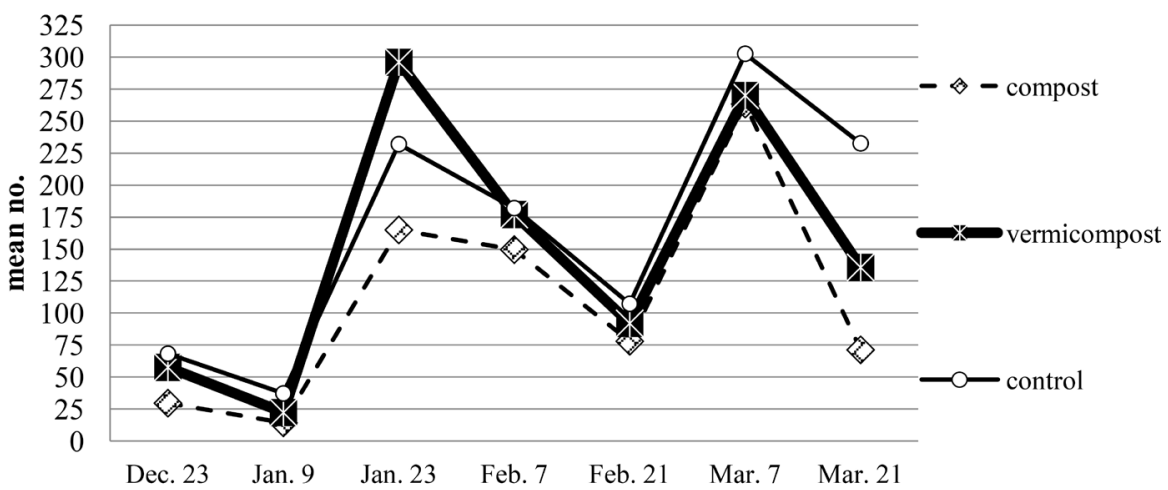

Figure 1. Aphids mean numbers throughout quinoa growing season (Dec. till March) in compost, vermicompost and control treatments. 
difference between treatments where $\mathrm{p}=0.001$. During the month of February, on the $7^{\text {th }}$, population of $E$. decipiens increased to reach $17.7 \pm 4,26.7 \pm 3.8$ and $37 \pm 3.84$ in compost, vermicompost and control treatments, respectively. Two weeks later the numbers increased up to $42.3 \pm 3.6,41.7 \pm 4$ and $68 \pm 3.61$, in the three treatments, respectively. High significant differences were noticed in both dates, where on the $7^{\text {th }}$ of February $\mathrm{p}<0.001$ and on the $21^{\text {st }}$ no significant differences were found between compost and vermicompost $(p=0.3)$ whereas, control results and both fertilizers showed high significant differences as $\mathrm{p}=$ 0.003. Only one peak occurred during quinoa growth which was on the $7^{\text {th }}$ of March where numbers of E. decipiens increased as illustrated in Figure 2, while on the $21^{\text {st }}$ of March mean numbers of the pest decreased again till it reached 33 $\pm 1.6,20 \pm 2$ and $37.6 \pm 1.61$, in compost, vermicompost and control treatments, respectively, with high significant differences between all treatments $(\mathrm{p} \leq 0.001)$.

\section{3) Bemisia tabaci}

Whiteflies appeared early in quinoa crop (in December) where mean numbers of the pest on the yellow traps recorded zero, $5.3 \pm 1.5$ and $8.3 \pm 0.5$, in compost, vermicompost and control plots, respectively, with High significant differences between the three treatments, where $\mathrm{p}<0.001$. As shown in Figure 3, data

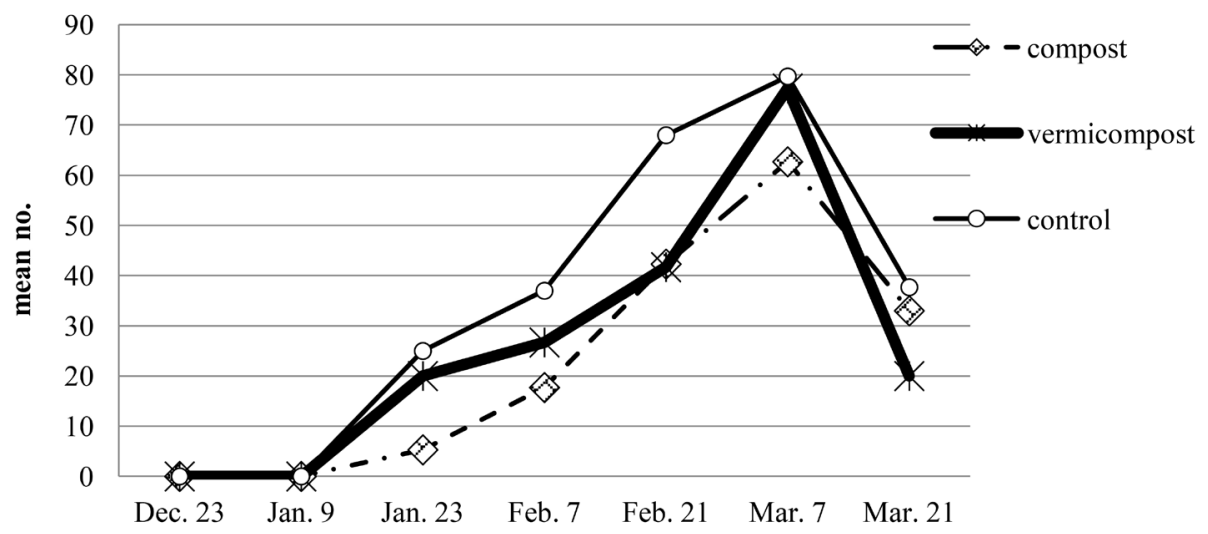

Figure 2. Leafhoppers mean numbers throughout quinoa growing season (Dec. till March) in compost, vermicompost and control treatments.

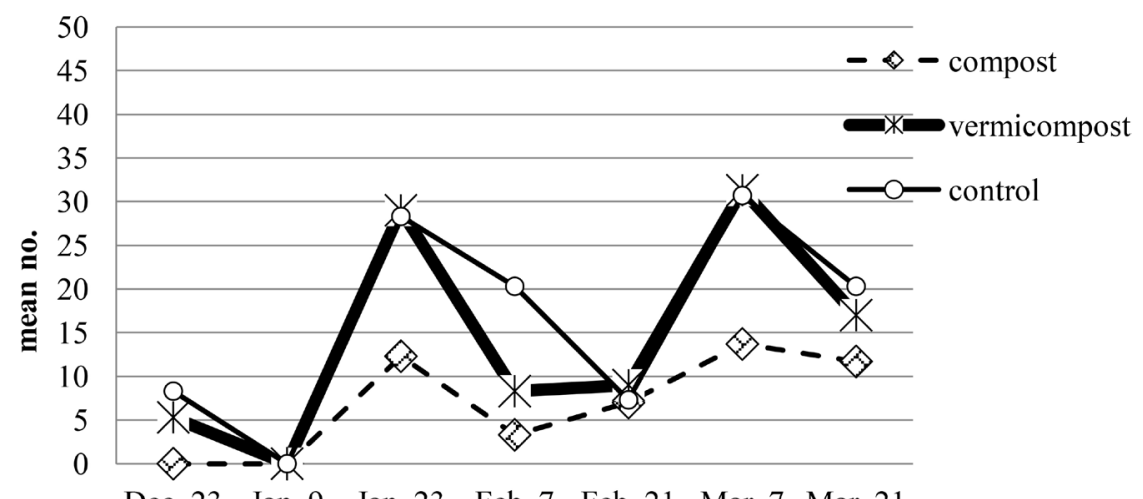

Dec. 23 Jan. 9 Jan. 23 Feb. 7 Feb. 21 Mar. 7 Mar. 21

Figure 3. Whiteflies mean numbers throughout quinoa growing season (Dec. till March) in compost, vermicompost and control treatments. 
collection after two weeks showed that B. tabaci disappeared from the field completely and then after another 14 days it appeared again recording mean numbers of $12.3 \pm 2.5,29 \pm 3.6$ and $28.3 \pm 3$ in compost, vermicompost and control plots, respectively, and this date (Jan. $23^{\text {rd }}$ ) represents the first peak of the pest population. High significant differences were noticed between compost on one hand and vermicompost and control on the other hand, where $\mathrm{p}<0.001$, while no significant differences appeared between control treatment and vermicompost $(\mathrm{p}=0.7)$.

On February $7^{\text {th }}$ mean numbers of the pest decreased to $3.3 \pm 1.2,8.3 \pm 1.5$ and $20.3 \pm 1.6$ in the three treatments, respectively. Mean number of whiteflies did not increase significantly when results were recorded 14 days later, whereas on the $7^{\text {th }}$ of March pest's mean number increased up to $13.7 \pm 2,31.3 \pm 2.2$ and $30.7 \pm 2.5$ in compost, vermicompost and control treatments, respectively, showing the second peak of the pest population. One way ANOVE test revealed high significant differences between quinoa fertilized with compost and quinoa in control and vermicompost plots where $\mathrm{p}<0.001$. Whereas, both vermicompost and control plots did not show any significant differences as $\mathrm{p}=0.8$. Finally, on the $21^{\text {st }}$ of March numbers of the pest declined again to reach $11.6 \pm 2.1,17 \pm 3.6$ and $20.3 \pm 1.5$, respectively.

\subsection{Predators in Quinoa Field}

Two types of predators were detected in quinoa field, i.e. the green lacewing Chrysoperla carnea and the ladybugs Coccinella vicina and Coccinella septempunctata. Numbers of predators were very low compared to the number of pests, as shown in Figure 4 \& Figure 5. During December, the green lacewing appeared in few numbers $(0.7 \pm 1.1,1.7 \pm 1.5$ and $2.7 \pm 0.6)$. One way ANOVA test showed significant differences between compost and both vermicompost and control as $\mathrm{p}=0.1$. There was no significant difference between vermicompost and the control treatments $(\mathrm{p}=0.005)$. On the other hand, the ladybugs did not appear till the $9^{\text {th }}$ of January. The Coccinella spp. recorded $2 \pm 1,6 \pm 0.6$ and $5.3 \pm 1.5$ in the three treatments, respectively. Mean numbers of $C$. carnea on the $9^{\text {th }}$ of January were $0.7 \pm 1.1,3 \pm 1$ and $4.7 \pm 1.1$ in compost, vermicompost and control plots, respectively.

Two weeks later, no ladybug individuals were found on the yellow sticky traps, whereas the green lacewing recorded mean numbers of $3 \pm 1.7,5 \pm 1$ and $12 \pm 1.5$, in the three treatments, respectively. One way ANOVA showed significant differences between all treatments $(\mathrm{p} \leq 0.001)$. Both predators disappeared again during the next two weeks and started to reappear on the $21^{\text {st }}$ of February. C. carnea recorded 0, $4.3 \pm 1$ and $5.3 \pm 2$, whereas Coccinella spp. mean numbers increased up to $4 \pm 1,10 \pm 0.9$ and $2.7 \pm 1.1$, in the three treatments, respectively (as illustrated in Figure 4). Mean numbers of $C$. carnea increased again to reach $8 \pm 1.5,14 \pm 1$ and $17 \pm 1.2$ in compost, vermicompost and control plots, respectively. On the $21^{\text {st }}$ of March, all treatments recorded zero number for this predator. 


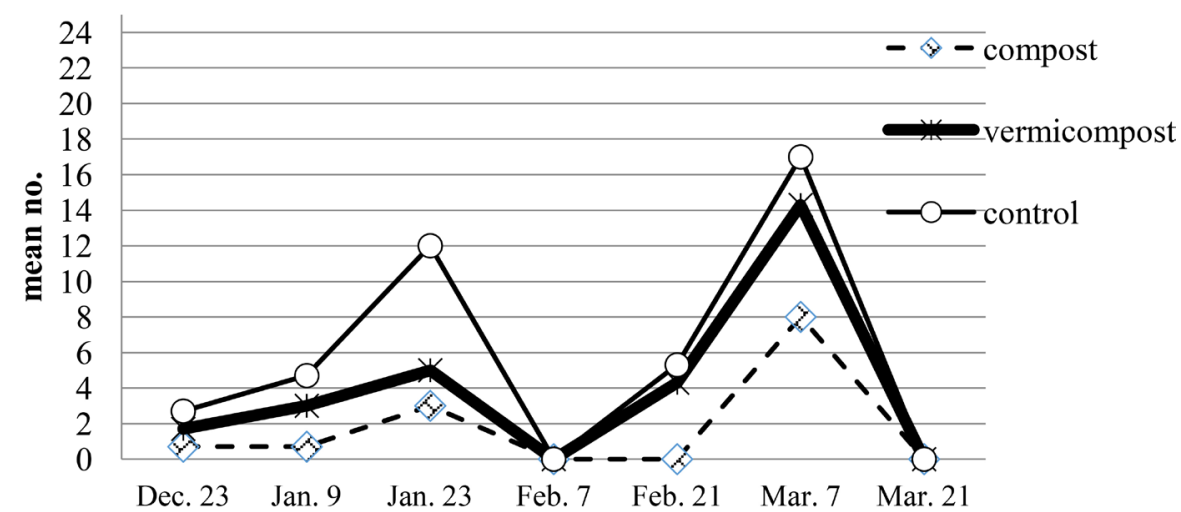

Figure 4. C. carnea mean numbers throughout quinoa growing season (Dec. till March) in compost, vermicompost and control treatments.

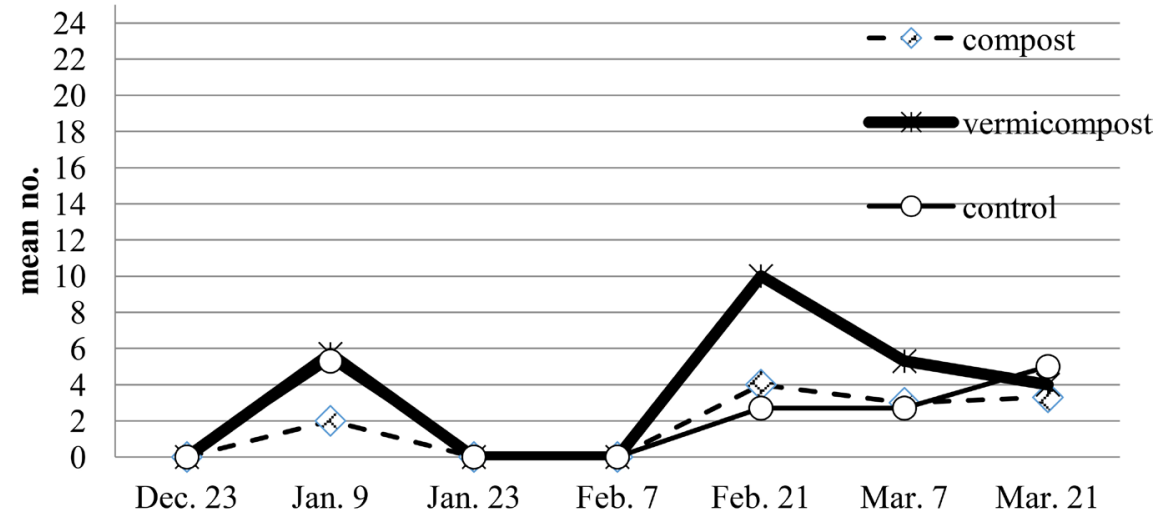

Figure 5. Coccinella mean numbers throughout quinoa growing season (Dec. till March) in compost, vermicompost and control treatments.

On the other hand, results of the ladybug on the two data collection dates of March were closed to each other, as shown in Figure 5.

\subsection{Parasitoids in Quinoa Field}

All the parasitoids detected in quinoa fields were aphid's parasitoids, i.e. the green bug aphid's parasitoids (Lysiphebus fabarum, Lysiphebus testacoipes), Bracon sp. and Trioxys sp. Those parasitoids appeared in quinoa field on the $23^{\text {rd }}$ of December recording mean numbers of $14 \pm 1.7,20.8 \pm 2$ and $30.6 \pm 3.7$ in compost, vermicompost and control plots, respectively. High significant differences appeared by ANOVA test as $\mathrm{p} \leq 0.001$. Mean numbers decreased when data were collected 14 days later as shown in Figure 6 and then increased again on the $23^{\text {rd }}$ of January to reach $38 \pm 5.2,73.3 \pm 15.2$ and $74.3 \pm 4$ in the three treatments, respectively. During the next two dates of data collection mean numbers of the parasitoids continued to decrease as shown in Figure 6, then numbers increased on the $7^{\text {th }}$ of March to record $18 \pm 5,9 \pm 1$ and $30.3 \pm 2.5$, respectively. One way ANOVA analysis proved significant differences between treatments as $\mathrm{p} \leq 0.001$. By the end of March parasitoids mean number decreased again to reach $3.3 \pm 1.5,4 \pm 1$ and $5 \pm 1$, respectively. No significant dif- 
ference was recorded as $\mathrm{p}=0.3$.

\subsection{The Effect of Fertilization Type on Insects' Incidence in Quinoa}

Results showed that the yellow sticky traps in the plots fertilized with compost caught the least numbers of insects during the two seasons. As shown in Figure 7 , in compost plot the total average mean numbers of aphids were 110 while both vermicompost and control average mean numbers were 160 and 166, respectively. Leafhoppers, on the other hand, recorded its highest number in the control plot (35) while the least number was recorded in the compost treatment, i.e. 23. Although B. tabaci was less in its number compared to the other two pests, still, its number in compost was less than those in vermicompost and control treatments as shown in the same figure.

Numbers of predators in the field were not high compared to the parasitoids where total average number of parasitoids was 12,19 and 25 in compost, vermicompost and control treatments whereas predators numbers did not exceed 6 individuals in their highest presence as shown in Figure 7.

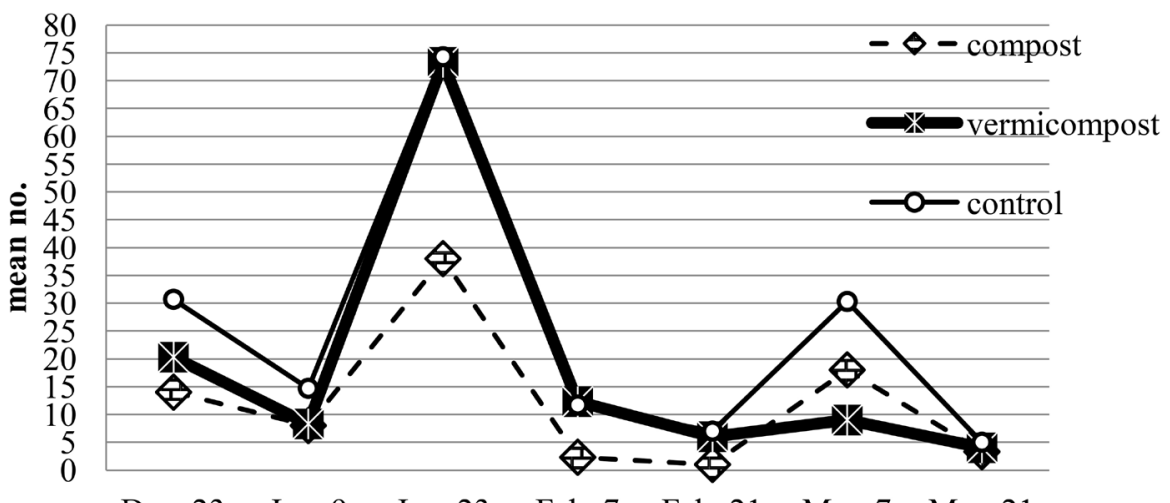

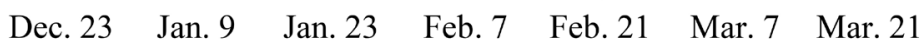

Figure 6. Parasitoids mean numbers throughout quinoa growing season (Dec. till March) in compost, vermicompost and control treatments.

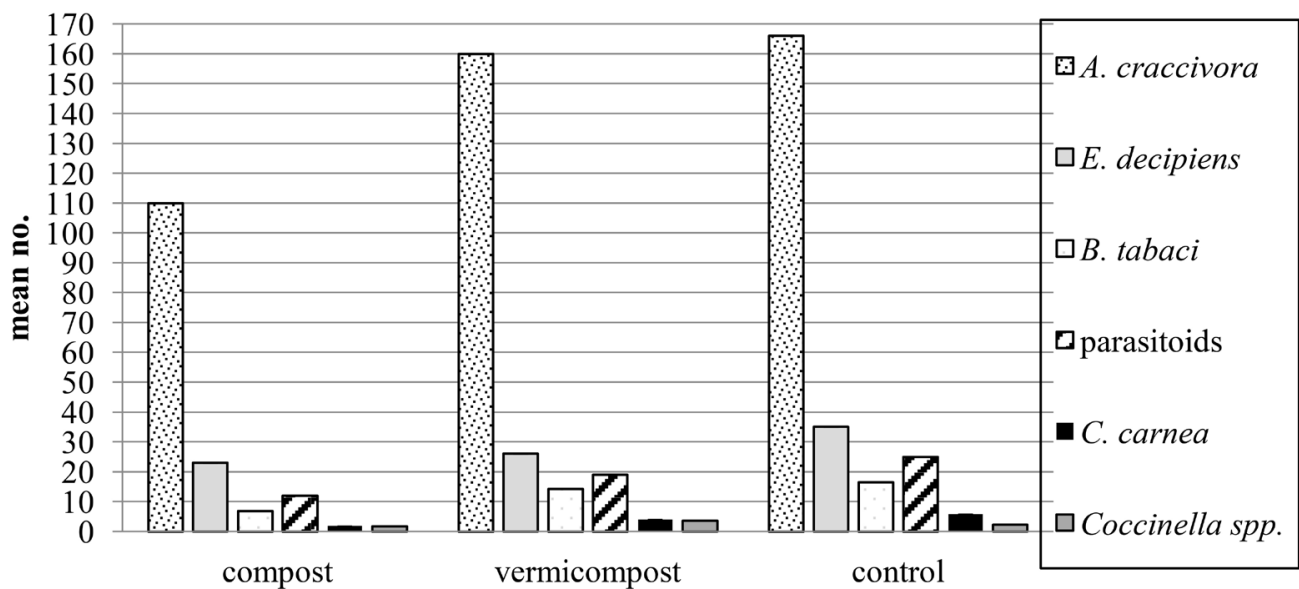

Figure 7. Average mean numbers of insects during quinoa growing seasons (Dec.-March) in compost, vermicompost and control treatments. 


\subsection{Effect of Fertilization on Quinoa Yield}

Fertilization, either vermicompost or compost, had a positive effect on quinoa yield/plant compared to control plot. The analysis of variance of data revealed high significant differentiation between both fertilizers and the control treatment $(\mathrm{p}=0.4)$ whereas no significant difference was noticed between the two fertilizers. Both fertilizers resulted in seed yield of $27 \pm 1.9$ and $26.4 \pm 1 \mathrm{gm}$. plant, respectively, whereas control plants gave yield of $23.6 \pm 1.4 \mathrm{gm}$. plant, as shown in Figure 8(a).

Further, 1000 seeds weight reached in case of vermicompost plots $467.4 \pm 39$ gm. while control treatment gave the least weight, i.e. $363.25 \pm 41 \mathrm{gm}$. and compost fertilized plants gave 1000 seeds weight of $353 \pm 30 \mathrm{gm}$. as illustrated in Figure 8 (b). Significant differences were noticed between all treatments, yet, it was higher between vermicompost and both control and compost treatments, i.e. $\mathrm{p}<0.001$.

On the other hand, vermicompost showed higher yield values per ha compared to both compost and control plots, i.e. $843 \pm 90,801 \pm 92$ and $771 \pm 92$ $\mathrm{Kg} / \mathrm{ha}$, respectively (Figure $8(\mathrm{c})$ ). Data analysis proved there were high significant
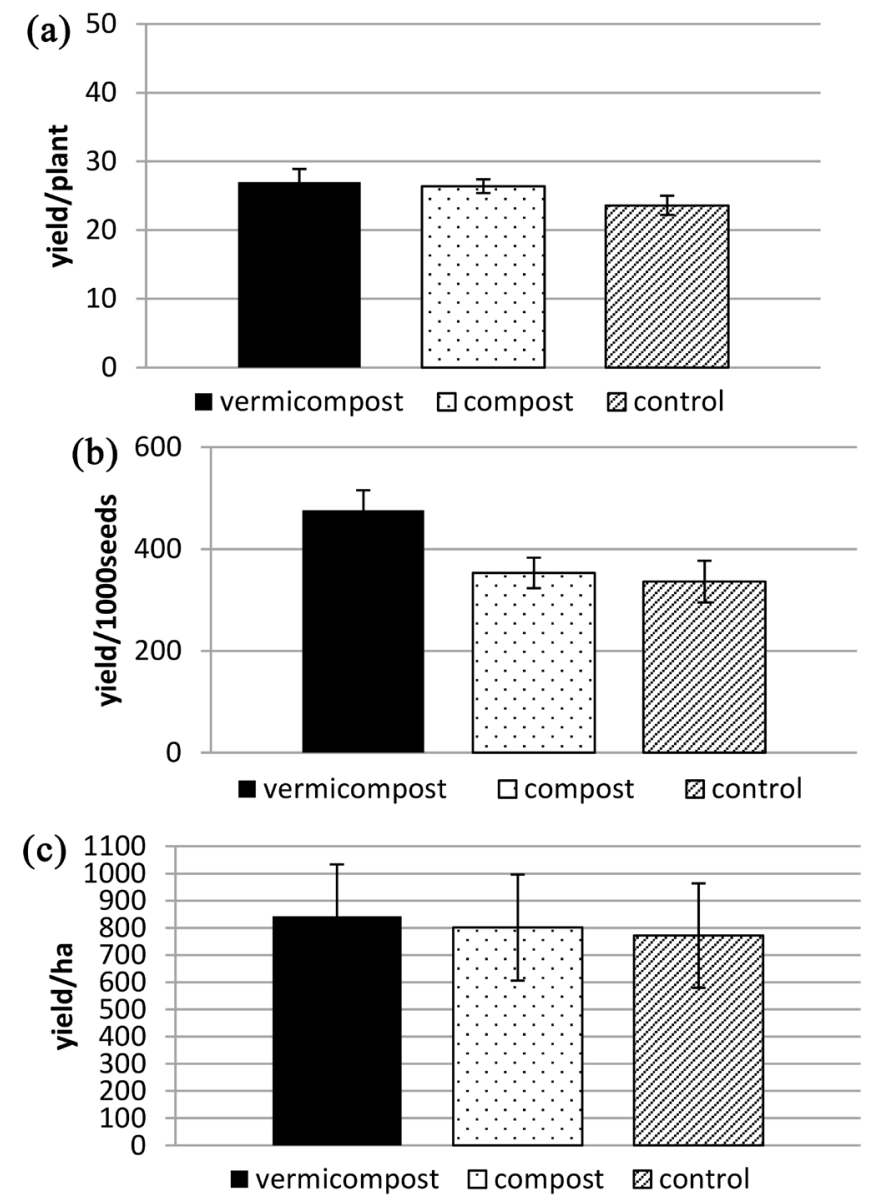

Figure 8. Quinoa yield in relation to used fertilizers and control treatment ((a) yield/plant, (b) yield/ ha and (c) weight of 1000 seeds). 
differences between vermicompost yield and both control and compost ( $\mathrm{p}=$ 0.86 ), whereas compost and control plots showed no significant differences $(\mathrm{p}<$ $0.001)$.

\section{Discussion}

Food security is one of the main challenges in Egypt, despite the availability of different natural resources; agriculture did not achieve the sufficient production increase to meet food demand, which in return increased food gap [12].

Two main questions are important to answer in the context of the current study:

\subsection{Why Organic Fertilizers?}

Reaching high yielding production occurs through good nutrition management. Several researchers discussed the importance of organic fertilization in improving plant health. Organic fertilization keeps soil moisture as organic matter improves soil water-holding capacity and increases water and nutrients availability for plants which in return gives strong and healthy crops with high production rates and less pests' infestation, something that is not provided by synthetic fertilization [25] [26]. Crops grown in organic fertilized area harbor less number of insect pests [27]. Moreover, organic fertilizers found to be more effective than chemical fertilizers in inducing rice growth and its tolerance to insect pests and diseases [28]. Application of organic fertilizers was sound effect to protect natural enemies under field condition. Shifting from organic to chemical soil management increased the potential of certain insects and diseases to cause economic losses [29].

\subsection{Why Quinoa Crop?}

Egypt has huge wheat gap, as the total production of wheat grains covers only $55 \%$ of the Egyptian needs and therefore, it is extremely necessary to search for suitable alternatives that could be integrated in making wheat flour bread to overcome the wheat gap and satisfy consumers' needs [30]. Quinoa flour can partly replace wheat flour in baked products [31]. Besides, quinoa is a drought-tolerant crop that resists adverse conditions, has a high nutritive value and is able to adapt different ecological environments and climates [32]. Further, quinoa has the highest income and is the most profitable compared to other grain crops such as wheat, soybean and canola [12].

\subsection{Pests' Population and Quinoa Crop}

Considering the above mentioned issues and as quinoa is a new crop in Egypt, more efforts are needed to raise awareness about all aspects related to quinoa's cultivation. The current study investigated the effect of compost and vermicompost on quinoa yield, pests' and natural enemies' incidence and population dynamics.

No specialized quinoa pests were found, rather, polyphagous pests were de- 
tected together with generalized natural enemies. This finding is in accordance with what Rasmussen et al. [16] declared. Few types of pests were found in the current experimental field, i.e. the black legume aphid A. craccivora, the potato leafhopper E. decipiens and the whitefly B. tabaci.

Several authors mentioned the association of Aphis spp. in quinoa fields, i.e. [33] [34] [35]. Additionally, Aphis was stated as an important quinoa pest in Europe [16]. Nampeera et al. [36] mentioned that $87 \%$ of their survey respondents, in Kenya, determined aphids as a major pest attacking amaranths spp. and 96.8\% ranked them as number-one insect pest. They also declared whiteflies as one of the pests attacking amaranths and causing damage. Quinoa shoots were also found to be attacked by sapsuckers (Aphididae and Cicadellidae) [37]. On the other hand, leafhoppers were declared as one of the pests attacking quinoa crop [16]. This data resembles the results obtained in the current study as these three pests were detected in the experimental area and aphids were the most abundant pest compared to the other two pests, i.e. whiteflies and leafhoppers.

It was noticed that aphids peaked twice during quinoa growth season, i.e. $23^{\text {rd }}$ of January and $7^{\text {th }}$ of March; these results are in conformity with Ya' bar et al. [37] who revealed that Aphididae had two peaks, at the beginning and end of quinoa growth season.

It is noteworthy that the present investigation provides basic information on seasonal incidence of whitefly on quinoa crop, as no data was found in the literature concerning this issue; rather the pest population was studied on many other crops. In the current study whiteflies peaked two times, i.e. $23^{\text {rd }}$ January and $7^{\text {th }}$ March (the same dates of aphids peaks). This confirms the findings of Yadav et al. [38] and Swathi [39] who declared that whiteflies peaked two times also but during tomato, soybean and green gram growth seasons in India. It seems that the pest behaves the same way in quinoa cultivation as demonstrated by the current findings.

The present study is also considered as first attempt that broadens our knowledge on the dynamics of potato leafhoppers on quinoa crop. It was proved that this pest peaked one time only during quinoa growth season; on the $7^{\text {th }}$ of March. This might be due to the increase in temperature and decrease in the relative humidity $\left(19^{\circ} \mathrm{C}\right.$ and $\left.53 \%\right)$ compared to the other months. A similar belief was expressed by Naseri et al. [40] and Rassoulian et al. [41] who said that population density of leafhoppers increased with increasing temperature and decreasing relative humidity on bean and soybean. Yet, other researchers, i.e. [42] [43] stated that E. decipiens peaked two times on kidney bean and some other plantation under Egyptian conditions. Thus, it could be concluded that plant species might have an effect on the population dynamics of E. deipiens.

The current investigation proved that although compost and vermicompost showed direct effect on the mean numbers of pests attacking quinoa crop under the experimental condition, yet, the date each pest peaked did not change from one fertilizer to the other. 
Likewise, this research demonstrated that pests found in organic fertilized quinoa plots are low in numbers compared to those in unfertilized plots. Altieri and Clara [29] found similar results and mentioned that crops grown in soils with organic matter exhibit lower abundance of several insect herbivores, reductions that could be attributed to lower nitrogen content in organically farmed crops. They added that quinoa plants fertilized with compost attracted less numbers of pests as proved in the current study. The superior of compost over vermicomopost might be explained according to Saranraj and Stella [44] who said that during preparation of vermicompost it retains more $\mathrm{N}$ than the traditional composts, therefore, using vermicompost increases the levels of total nitrogen in the soil and subsequently decreases plant resistance to pests as mentioned above. This interpretation could be applied here, as the parameters and minerals analysis of both compost and vermicompost proved that the percentage of nitrogen in vermicompost is double its percentage in compost, i.e. 1.2 and $2.4 \%$.

\subsection{Natural Enemies' Population in Quinoa Field}

Parasitoids and predators were present in quinoa field. Four species of parasitoids were detected, i.e. Lysiphebus fabaru, Lysiphebus testacoipes, Bracon sp. and Trioxys sp. whereas, predators were represented by the existence of two families, i.e. family Chrysopidae: Chrysoperla carnea and family Coccinellidae: Coccinella vicina and Coccinella septempunctata. It was noticed that parasitoids peaked two times; January, $23^{\text {rd }}$ and March, $7^{\text {th }}$ which happened to be the same peak dates of aphids, grasshoppers and whiteflies. On the other hand, although predators were few in numbers; they peaked twice as well. Results verified that parasitoids appeared much earlier than predators and their mean numbers in the field were higher than predators in all treatments, although their numbers were less in compost treatments than both vermicompost and control plots; that might be attributed to the decrease in pests' numbers in compost treatments. The superiority of parasitoids over predators in the current investigation might be assigned to their early appearance in the field which allowed their early parasitism that led to reduction in predation rate and consequently predators' numbers. This explanation is supported by the findings of Tan et al. [45] who justified that the predator Harmonia axyridis of the family Coccinellida exhibited the lowest rates of predation when released in the presence of whitefly specific parasitoids (Encarsia formosa and Encarsia sophia) and showed a significant preference for non-parasitized nymphs as prey. Further research work is needed to prove this explanation. Reduction in predators number might also be attributed to the prevailed temperature during the current experiment which was $14.7^{\circ} \mathrm{C}$, $14^{\circ} \mathrm{C}$ and $16.1^{\circ} \mathrm{C}$ during December, January and February, respectively, and which is not favorite for the development of coccinellidae individuals as proved by Katsarou et al. [46] who stated that mortality of immature stages of these predators was the highest at the temperature of $14^{\circ} \mathrm{C}$ whereas egg and larval 
mortality exceeded $80 \%$ at $17^{\circ} \mathrm{C}$ and $18^{\circ} \mathrm{C}$. The same verification could be applied to $C$. carnea as low temperature causes high mortalities among the predator individuals and the suitable development temperature ranges from $25^{\circ} \mathrm{C}$ to $31^{\circ} \mathrm{C}$ [47]. Costa and Stary [48] proved that L. testaceipes follows its host aphids apparently in all environments and its occurrence covers most of the season.

\subsection{Quinoa Yield}

Results showed that using compost and vermicompost enhanced crop yield (seeds/plant, weight of 1000 seeds and yield/ha). Yet, vermicompost resulted in more yield when compared to compost and control. These results are in accordance with many researchers; Islam et al. [23] demonstrated that vermicompost application showed higher result for growth, yield indices and nutrient content of Amaranthus viridis compared to conventional aerobic compost and therefore, they recommended farmers to use vermicompost in crop production. Edwards et al. [49] reported that vermicompost has a much finer structure than compost and there is a considerable difference in their performances and effects on plant growth. In addition, Saranraj and Stella [44] stated that vermicompost plays a major role in crops growth and yield.

\section{Conclusions}

In a country characterized by a desert area that exceeds $90 \%$ and limited water resources, tolerant crops are needed. Through the current work it is concluded that:

- Quinoa is a promising solution to bridge wheat gap production in Egypt.

- Organic fertilizers can be the key to increase productivity and decrease pests' infestation in quinoa.

- Vermicompost is more effective in raising quinoa yield than compost although quinoa fertilized with it attracted more pests; therefore, an integrated pest management approach should be implemented to overcome this point in which natural enemies should play the main role, especially now that we know their peaks dates which is a good start for IPM interventions.

- More efforts should be made to raise farmers' awareness of vermicompost importance and efficiency and the community acceptance to quinoa as wheat alternative or supplement.

\section{Acknowledgements}

Thanks are due to Dr. Atef Abdel Azez, Director of the Central Lab of Organic Agriculture, for providing the organic fertilizers used in this work. The author appreciates very much the assistant of Dr. Mohamed Kamal, Dr. Azam Ahmed and colleagues from the Plant Protection Research Institute for providing the sticky traps and identification and counting of insects. I would specifically like to thank Prof. Dr. Hashem Ibrahim for the help he offered during the statistical analysis of this research. Thanks are also due to Miss Rehab El Sayed for her 
kind assistance during the implementation and data collection of this research.

\section{Conflicts of Interest}

The author declares no conflicts of interest regarding the publication of this paper.

\section{References}

[1] Ahamed, N.T., Singhal, R.S. Kulkarni, P.R. and Pal, M.A. (1998) Lesser-Known Grain, Chenopodium quinoa: Review of the Chemical Composition of Its Edible Parts. Food and Nutrition Bulletin, 19, 61-70. https://doi.org/10.1177/156482659801900110

[2] Jacobsen, S.E. (2003) The Worldwide Potential for Quinoa (Chenopodium quinoa Willd.). Food Reviews International, 19, 167-177. https://doi.org/10.1081/FRI-120018883

[3] Wright, K.H., Pike, O.A., Fairbanks, D.J. and Huber, C.S. (2002) Composition of Atriplex hortensis, Sweet and Bitter Chenopodium quinoa Seeds. Journal of Food Science, 67, 1383-1385. https://doi.org/10.1111/j.1365-2621.2002.tb10294.x

[4] Valencia-Chamorro, S.A. (2003) Quinoa. In: Caballero, B., Ed., Encyclopedia of Food Science and Nutrition, Academic Press, Amsterdam, 4895-4902. https://doi.org/10.1016/B0-12-227055-X/00995-0

[5] Jancurová, M., Minarovicová, L. and Dandár, A. (2009) Rheological Properties of Dough with Buckwheat and Quinoa Additives. Chemical Papers, 63, 738-741. https://doi.org/10.2478/s11696-009-0073-Z

[6] Koziol, M.J. (1992) Chemical Composition and Nutritional Evaluation of Quinoa (Chenopodium quinoa Willd.). Journal of Food Composition and Analysis, 5, 36-68. https://doi.org/10.1016/0889-1575(92)90006-6

[7] Shams, A.S. (2010) Combat Degradation in Rainfed Areas by Introducing New Drought Tolerant Crops in Egypt. 4th International Conference on Water Resources and Arid Environments, Riyadh, 5-8 December 2010, 575-582.

[8] El-Ramady, H., Samia, M. and Lowell, N. (2013) Sustainable Agriculture and Climate Changes in Egypt. E. Sustainable Agriculture Reviews, 12, 41-95. https://doi.org/10.1007/978-94-007-5961-9 2

[9] Jacobsena, S.E., Mujicab, A. and Ortizb, R. (2003) The Global Potential for Quinoa and Other Andean Crops. Food Review International, 19, 139-148. https://doi.org/10.1081/FRI-120018880

[10] El-Sayed, J. (2018) Why Is Egypt's Government Promoting Quinoa Cultivation? http://www.egypttoday.com/Article/2/48869/Why-is-Egypt\%E2\%80\%99s-governme nt-promoting-quinoa-cultivation

[11] Schlick, G. and Bubenheim, D.L. (1993) Quinoa: An Emerging "New" Crop with Potential for Celss. A Technical Report, NASA Ames Research Center, Moffett Field, CA. https://ntrs.nasa.gov/search.jsp?R=19940015664

[12] Hossam, K. and Helmy, N. (2014) The Economics of Quinoa Production to Address the Food Problem Security and Reduce Food Poverty Gap in Egypt. Middle East Journal of Applied Sciences, 4, 122-141.

[13] DANIDA (2012) Development of Quinoa in Egypt. http://egypten.um.dk/en/aboutus/news/newsdisplaypage/?newsid=500ad6da-4da4$\underline{485 b-b 42 e-0 f 6 d c 4 c 1 d 781}$ 
[14] Oelke, E.A., Putnam, D.H., Teynor, T.M. and Oplinger, E.S. (1992) Quinoa. https://www.hort.purdue.edu/newcrop/afcm/quinoa.html

[15] Sigsgaard, L., Jacobsen, S.E. and Christiansen, J.L. (2008) Quinoa, Chenopodium quinoa, Provides a New Host for Native Herbivores in Northern Europe: Case Studies of the Moth, Scrobipalpa atriplicella, and the Tortoise Beetle, Cassida nebulosa. Journal of Insect Science, 8, 50-53. https://doi.org/10.1673/031.008.5001

[16] Rasmussen, C., Lagnaoui, A. and Esbjerg, P. (2003) Advances in the Knowledge of Quinoa Pests. Food Reviews International, 19, 61-75. https://doi.org/10.1081/FRI-120018868

[17] Tawfik, H., Haitham, B. and Ayat, M. (2015) Survey on Diseases and Pests Attack Quinoa in Egypt. Sixth International Scientific Agricultural Symposium, Agrosym 2015.

[18] Ramesh, P., Singh, M. and Subba Rao, A. (2005) Organic Farming: Its Relevance to the Indian Context. Current Scientist, 88, 561-568.

[19] Altieri, M.A., Clara, I.N. and Marlene, A.F. (2012) Manage Insects on Your Farm: A Guide to Ecological Strategies, Handbook Series, Book 7. Sustainable Agriculture Research and Education (SARE) College Park, MD.

[20] Banfield-Zanin, J.A., Rossiter, J.T. Wright, D.J., Leather, S.R. and Staley, J.T. (2012) Predator Mortality Depends on Whether Its Prey Feeds on Organic or Conventionally Fertilized Plants. Biological Control, 63, 56-61. https://doi.org/10.1016/j.biocontrol.2012.05.008

[21] Rajkhowa, D.J., Saikia, M. and Rajkhowa, K.M. (2002) Effect of Vermicompost with and without Fertilizer in Green Gram. Legume Research, 25, 295-296.

[22] Papastylianou, P., KakaboukI, I., Tsiplakou, E., Travlos, I., Bilalis, D., Hela, D., Chachalis, D., Anogiatis, G. and Zervas, G. (2014) Effect of Fertilization on Yield and Quality of Biomass of Quinoa (Chenopodium quinoa Willd.) and Green Amaranth (Amaranthus retrorlexus L.). Bulletin UASVM Horticulture, 71, 28 -292. https://doi.org/10.15835/buasvmcn-hort:10411

[23] Islam, M.S., Hasan, M., Rahman, M.M., Uddin, M.N. and Kabir, M.H. (2016) Comparison between Vermicompost and Conventional Aerobic Compost Produced from Municipal Organic Solid Waste Used in Amaranthus viridis Production. Journal Environment Science \& Natural Resources, 9, 43-49. https://doi.org/10.3329/jesnr.v9i2.32150

[24] Sreenivas, Ch., Muralidhar, S. and Rao, M.S. (2000) Yield and Quality of ridge Gourd Fruits as Influenced by Different Levels of Inorganic Fertilizers And Vermicompost. Annals of Agricultural Research, 21, 262-266.

[25] Ouattara, K., Ouattara, B., Assa, A. and Sedogo, P.M. (2006) Long-Term Effect of Ploughing and Organic Matter Input on Soil Moisture Characteristics of a Ferric Lixisol in Burkina Faso. Soil and Tillage Research, 88, 217-224. https://doi.org/10.1016/j.still.2005.06.003

[26] Wesseling, J., Stoof, C., Ritsema, C., Oostindie, K. and Dekker, L. (2009) The Effect of Soil Texture and Organic Amendment on the Hydrological Behavior of Coarse Textured Soils. Soil Use Manage, 25, 274-283. https://doi.org/10.1111/j.1475-2743.2009.00224.x

[27] Ejaz, P., Shahid, H., Rashid, A. and Shahid, N. (2003) Comparative Effect of Organic and Synthetic Fertilizers on the Infestation of Sucking and Bollworms Insect Pest Complex on Different Varieties of Cotton (Gossypium hirsutum L.). Asian Journal 
of Plant Sciences, 2, 1135-1137.

[28] Chau, L.M. and Heong, K.L. (2005) Effects of Organic Fertilizers on Insect Pest and Diseases of Rice. Omonrice, 13, 26-33.

[29] Altieri, M.A. and Clara, I.N. (2003) Soil Fertility Management and Insect Pests: Harmonizing Soil and Plant Health in Agro Ecosystems. Journal Soil and Tillage Research, 72, 203-2011. https://doi.org/10.1016/S0167-1987(03)00089-8

[30] Litwinek, D., Gambuś, H., Mickowska, B., Zięć, G. and Berski, W. (2013) Amino Acids Composition of Proteins in Wheat and Oat Flours Used in Breads Production. Journal of Microbiology, Biotechnology and Food Sciences, 2, 1725-1733. https://search.proquest.com/openview/0a0ccd3ae387c2d48a59bf8145387f4c/1?pq-o $\underline{\text { rigsite }=\text { gscholar } \& \mathrm{cbl}=1966353}$

[31] El-Sohaimy, S.A., Taha, M.G. and Zeitoun, M.A. (2019) Nutritional, Physicochemical, and Sensorial Evaluation of Flat Bread Supplemented with Quinoa Flour. International Journal of Food Science, 2019, Article ID: 4686727. https://doi.org/10.1155/2019/4686727

[32] El-assiuty, E.M., Fawziya, M.B. and Fahmy, Z.M. (2014) First Record of Downy Mildew of Quinoa in Egypt. Egypt Journal of Agricultural Research, 92, 871-872.

[33] Gesinski, K. (1999) In: Test of Quinoa (Chenopodium quinoa Willd.) in Poland. Memorios, Primer Taller International sobre Quinua-Recursos Geneticos y Sistemas de Producción, 5.

[34] Leiter, G., Amparo, R., Guillermo, C., Blanka, K., Radim, C. and Deisy, R. (2014) Bridging the Gap between Increasing Knowledge and Decreasing Resources: Studying Quinoa Chenopodium quinoa Willd Adaptability from Tropical to Temperate Conditions.

https://www.researchgate.net/publication/323915870 Bridging the gap between $\mathrm{i}$ ncreas-

ing knowledge and decreasing resources Studying Quinoa Chenopodium quin oa Willd Adaptability from Tropical to Temperate Conditions

[35] Whitney, S.C., Boris, C.K. and Tianrong, Q. (1990) Insects Associated with Quinoa, Chenopodium quinoa, in Colorado. Journal of the Kansas Entomological Society, 63, 195-199.

[36] Nampeera, E.L., Gail, R.N., Sue, L.B., Sharon, M.T., Dorothy, M.M., John, M.W., et al. (2019) Farmers' Knowledge and Practices in the Management of Insect Pests of Leafy Amaranth in Kenya. Journal of Integrated Pest Management, 10, 31. https://doi.org/10.1093/jipm/pmz029

[37] Yabar, E., Gianoli, E. and Echegaray, E.R. (2002) Insect Pests and Natural Enemies in Two Varieties of Quinoa (Chenopodium quinoa) at Cusco, Peru. Journal Applied Entomology, 126, 275-280. https://doi.org/10.1046/j.1439-0418.2002.00664.x

[38] Yadav, P., Banerjee, S., Gupta, M.P. and Yadav, V.K. (2015) Effect of Weather Factors on Seasonal Incidence of Insect Pests of Soybean. Journal of Multidisciplinary Advance Research, 4, 46-51.

[39] Swathi, B. (2017) Studies on Seasonal Fluctuation of Whitefly Population on Major Kharif and Rabi Crops and their Monitoring through Yellow Sticky Traps. Department of Entomology College of Agriculture, Jawaharlal Nehru Krishi Vishwa Vidyalaya, Jabalpur.

[40] Naseri, B., Fathipour, Y., Moharramipour, S. and Hosseininaveh, V. (2009) Comparative Life History and Fecundity of Helicoverpa armigera (Lepidoptera: Noctuidae) on Different Soybean Varieties. Entomological Science, 12, 147-154. 
https://doi.org/10.1111/j.1479-8298.2009.00310.x

[41] Rassoulian, G.R., Sardarbandeh, H. and Pakdel, A.K. (2005) Study of Soybean Leafhoppers Fauna and an Investigation on Biology of Dominant Species Empoasca decipiens (Paoli) in Karaj Area. Communication in Agricultural and Applied Biological Science, 70, 671-675.

[42] Gamila, Y.A., El-Husseini, M.M., Al-Shemi, H.A. and Sayeda, S.A. (2016) Molecular Identification of Five Egyptian Ladybird Beetles Based on 28S rDNA (Coleoptera: Coccinellidae). Egyptian Journal of Biological Pest Control, 26, 153-156.

[43] Mahmoud, Y.A., Amr, E.M. and Ebadah, I.M.A. (2011) Some Ecological Behaviors of the Leafhopper, Empoasca decipiens (Paoli) on Some Winter Plantations in Egypt. Journal of Basic and Applied Scientific Research, 1, 88-94.

[44] Saranraj, P. and Stella, D. (2012) Vermicomposting and Its Importance in Improvement of Soil Nutrients and Agricultural Crops. Novus Natural Science Research, 1, 14-23.

[45] Tan, X., Nana, H., Ricardo, R., Nicolas, D., Su, W. and Feng, G. (2016) Mixed Release of Two Parasitoids and a Polyphagous Ladybird as a Potential Strategy to Control the Tobacco Whitefly Bemisia tabaci. Scientific Reports, 6, 28245. https://doi.org/10.1038/srep28245

[46] Katsarou, I., Margaritopoulos, J.T. and John, A. (2005) Effect of Temperature on Development, Growth and Feeding of Coccinella septempunctata and Hippodamia convergens Reared on the Tobacco Aphid, Myzus persicae nicotianae. Biological Control, 50, 565-588. https://doi.org/10.1007/s10526-004-2838-1

[47] Pathan, S.N., Aslam, B., Imtiaz, A., Abdul Ghani, L., Kumbhar, M., Rajput, L., Bukhari, S., et al. (2016) Influence of Varying Temperature on Life Stages of Chrysoperla carnea (Stephens) Under Laboratory Conditions. Journal of Basic \& Applied Sciences, 12, 388-393. https://doi.org/10.6000/1927-5129.2016.12.60

[48] Costa, A. and Stary, P. (1988) Lysiphlebus testaceipes, an Introduced Aphid Parasitoid in Portugal (Hym. Aphidiidae). Entomophaga, 33, 403-412. https://doi.org/10.1007/BF02373176

[49] Edwards, C.A. and Lofty, J.R. (1988) Nitrogenous Fertilizers and Earthworm Population in Agricultural Soul. Soil Biology and Biochemistry, 14, 515-521. https://doi.org/10.1016/0038-0717(82)90112-2 